\begin{tabular}{|lcc|}
\hline & Uluslararası Sosyal ve Eğitim Bilimleri Dergisi \\
International Journal of Social and Educational Sciences \\
Cilt 7, Sayı 14, Aralı 2020 \& Vol 7, No 14, December 2020
\end{tabular}

\title{
Lisans Programlarındaki Tarih Derslerinde Birinci El Kaynakların Kullanım Durumu*
}

\author{
The Status of Using Primary Sources in Undergraduate History Courses
}

Ramazan Kaya** \& Büşra Kahveci Gül***

$\ddot{\mathbf{O z}}$

Bu çalışmanın amacı, lisans programlarında yer alan tarih derslerinde birinci el kaynakların kullanım durumunu tespit etmektir. Nitel veri toplama yöntem ve araçlarının kullanıldığı bu araştırmada betimsel tarama modeli benimsenmiştir. Araştırmanın çalışma grubunu 2016-2017 akademik yılında Atatürk Üniversitesi Kazım Karabekir Eğitim Fakültesi, Atatürk Üniversitesi Edebiyat Fakültesi ve Erzurum Teknik Üniversitesi Edebiyat Fakültesi’nde görev yapan ve tarih derslerini yürüten toplam 27 öğretim üyesi ile bu fakültelerdeki tarih eğitimi anabilim dalı ve tarih bölümlerinin 4. sınıflarında öğrenimlerini sürdüren toplam 70 öğrenci oluşturmaktadır. Araştırmada veri toplama aracı olarak yarı yapılandırılmış görüşme formu ve açık uçlu anket formu birlikte kullanılmıştır. Çalışmada elde edilen veriler içerik analizi ile çözümlenmiştir. Çalışmanın sonucunda öğretim üyelerinin derslerinde kaynakları çeşitli türlerde kullandıkları görülmüştür. Ancak bu kaynakları sınıflarda geleneksel biçimde ele aldıkları, ilgili literatürde gösterildiği üzere üst düzey düşünme becerilerinin geliştirilmesine yönelik pek kullanmadıkları tespit edilmiştir. Buna ek olarak; gerek öğretim üyelerinden gerekse öğrencilerden elde edilen bulgular; birinci elden kaynaklarla ilgili uygulamalı çalışmaların sınırlı kaldığını, öğrenci merkezli etkinliklere pek başvurulmadığını ve öğretim üyeleri tarafından daha çok görsellerinin gösterilip tanıtıldığını ortaya koymuştur. Öğretmen adaylarının aldıkları eğitimin ortaöğretim derslerinde birinci el kaynakları eğitsel amaçlı kullanmak için yeterli olmadığı görülmektedir.

Anahtar Kelimeler: Kanıt, birinci el kaynak, tarihsel kanıt, kanıt temelli öğrenme, öğretmen yetiştirme.

\begin{abstract}
The purpose of this study is to determine the status of use of primary sources in history courses in undergraduate programs. A descriptive survey method was adopted in the study in which qualitative data collection method and tools were used. The sample of the research consisted of 27 lecturers who taught history courses in Kazım Karabekir Faculty of Education in Ataturk University, Faculty of Letters in Ataturk University and Faculty of Letters in Erzurum Technical University and 70 students who were at the 4th grade of the history education and history departments in these faculties in the 2016-2017 academic year. In the research, semi-structured interview form and open-ended questionnaire form were used together as data collection tools. The data obtained in the study were analysed via content analysis. As a result of the study, it was revealed that the lecturers in their lessons used variety of sources. However, it was determined that they used these sources traditionally in the lessons and they did not use them to develop higher-order thinking skills as explained in literature. In addition to this, the findings obtained both from the lecturers and students revealed that the practical studies about primary sources were limited, student-centred activities were not preferred much, and lecturers mostly showed visuals and introduced them. It is seen that the education that teacher candidates received is not sufficient to use primary sources for educational purposes in secondary education classes.
\end{abstract}

Keywords: Evidence, primary sources, historical evidence, evidence-based learning, teacher training.

\footnotetext{
* Bu çalışma, Ramazan Kaya danışmanlığında Büşra KAHVECİ GÜL tarafından 2020 yılında Atatürk Üniversitesi, Eğitim Bilimleri Enstitüsü, Tarih Eğitimi Bilim Dalı'nda yapılan “Lisans Programlarındaki Tarih Derslerinde Birinci El Kaynak Kullanım Durumları" adlı yüksek lisans tezinin bulgularına dayalı olarak hazırlanmıştır.

** (Doç. Dr.); Atatürk Üniversitesi, ramco@ atauni.edu.tr, ORCID: 0000-0002-9481-2450

*** (Uzman); Atatürk Üniversitesi, busra.kahveci@icloud.com, ORCID: 0000-0001-8545-9985
}

Kaynak Gösterme: Kaya R, Gül, K, B. "Lisans Programlarındaki Tarih Derslerinde Birinci El Kaynakların Kullanım Durumu". Uluslararası Sosyal ve Eğitim Bilimleri Dergisi 7 (2020): 154-174. 


\section{Extended Summary}

\section{Introduction:}

Although the use of sources as an evidence in history education dated back to the beginning of 1900s, their popularity mainly increased with the new history approach in 1970s (see Sylvester, 1997, 12-17; Kabapınar, 2003, 40-41; 2014, 251-252; 2019, 29-30; Osborne, 2003; Keating \& Sheldon, 2011, 7-11; Dinç, 2014, 79-80). Source/evidence-based education in Turkey has had an opportunity to be applied with the educational curricula developed according to the constructivist learning theory. The teacher candidates who are expected to use the sources by integrating them with the activities during history education in elementary and secondary education levels are required to receive training at an adequate level considering this issue (Dilek \& Yapıc1, 2008, 343). Studies about using evidence were generally carried out in elementary school social studies course and secondary school history course levels in Turkey. The number of studies considering the role and importance of evidence-based practices in the pre-service teacher training and including evidence-based practices was quite limited (see Dilek \& Yapıcı (2008), Dönmez \& Altıkulaç (2014), Kiriş Avaroğulları \& Görgen, (2014), Kaya (2015), Avc1 Akçalı (2019)). This case of limitation experienced in literature has encouraged us to carry out studies in this field.

The purpose of this study is to determine the status of use of primary sources in history courses in undergraduate programs. With this aspect, it aims at revealing whether or not the history education students received at undergraduate level is satisfactory for the use of primary sources in secondary school history courses. The research explored the lectures' status, frequencies, and ways of using primary sources in history courses included in undergraduate programs and their purposes for using the primary sources as well as the students' status of receiving training about primary sources.

\section{Research Method:}

A descriptive survey method was adopted in the study in which qualitative data collection method and tools were used. The participants were chosen via convenience sampling, one of the purposeful sampling methods (see. Yıldırım \& Şimşek, 2013, 141). The reason for this is that the researcher is a graduate of Ataturk University and he can easily reach the university's lecturers and students. The sample of the study consisted of 27 lecturers, who taught history courses in Kazım Karabekir Faculty of Education (9) and Faculty of Letters in Ataturk University (16) and the Faculty of Letters in Erzurum Technical University (2) and $704^{\text {th }}$ grade students, 20 of whom studied at the Department of History Education in Kazım Karabekir Faculty of Education, 30 at the Department of History in Faculty of Letters in Ataturk University, and 20 at the Department of History in the Faculty of Letters in Erzurum Technical University, in the 2016-2017 academic year. The reason for the participation of departments of history in the study in addition to the history teaching departments is that the students studying in the department of history could apply for teaching positions due to the pedagogical formation education offered to them.

\section{Data Collection Tools:}

Semi-structured interview forms and open-ended questionnaire forms were used together for data collection. In this context, during the interviews with the lecturers, in-depth data were collected and in order to verify the data obtained, data were collected from the students via open-ended questionnaire forms. The interview and questionnaire questions were given to the experts in the field and they were asked to evaluate them. Considering the feedback given by the experts, the questions were finalized and piloted. The participants gave voluntary informed consent to participate in the interview and questionnaire questions. After the interviews, the responses given by the lecturers were transferred to Word program and they were showed to the participants after getting a printout of them, and their consent was obtained. At the end of the study, the data obtained from the semi-structured interviews and open-ended questionnaires were analysed via content analysis (see Yıldırım \& Şimşek, 2013, 260). 


\section{Results:}

It was determined that the majority of the lecturers interviewed used mainly archival documents, and then chronicles, pictures and photos, and memoirs as primary sources. It was found that the subject of the lesson specified the lecturers' use of sources. It was revealed that the lecturers used primary sources mainly for the purpose of showing where they obtained the information they explained to the students and grounding their knowledge, demonstrating the quality of the sources and how to use them, and presenting correct and reliable knowledge. It was revealed that the lecturers mostly showed and introduced the sources to the students with the help of a projector and then they used the sources of different parties together and compared them and finally taught students the qualities of the sources, where to find them, and how to use them.

It was determined from the statements of majority of students that primary sources including mainly archival documents, books and then chronicler's dates and memoirs were used in their lessons. The students stated that the frequency of using primary sources were determined according the pacing of the course. In addition, students stated that the visuals of the primary sources were mostly displayed, or examples were given by projecting slides on to a screen. Then, students determined that the texts were translated only in Epigraphy and Palaeography courses and ancient writing was introduced, the primary sources were read and evaluated together with the students and information was given about them.

It was found that most of the students received training based on the sources. It was determined that these teaching styles firstly included "theoretical education" about what the sources are and how to use them and then "applied education" about the use of primary sources.

\section{Discussion and Suggestions:}

This study generally revealed that the education students received during their undergraduate period was not completely adequate for them to carry out educational activities based on primary sources in secondary school history courses. Within the context of the study, it was revealed that primary sources were used traditionally in the classes, practical studies were limited, and the activities which students would join in were not properly used. In a study carried out by Dilek and Yapic1 $(2008,343)$ with pre-service history teachers, it was determined that the participants experienced variety of difficulties while working with the sources and it was suggested that pre-service teachers should receive a good education about working with the sources. Dönmez and Altıkulaç (2014, 938-939) conducted a study with pre-service social studies teachers and it was revealed in this study that the participants had some difficulties about using historical sources and they did not get adequate undergraduate education. In fact, it was determined in a study carried out by Kaya $(2015,2734)$ with pre-service history teachers that the most important reason for the problems that the participants experienced about the applications of evidence-based education was that they did not have any experience about using sources in their past and current education life. In a study carried out with pre-service history teachers by Avc1 Akçalı $(2019,243)$, the participants stated that the primary sources were sometimes used in their undergraduate program courses and without being exposed to critical examination.

These are the following suggestions proposed at the end of the study:

1- Lecturers should use the primary sources within the framework of activities in which students are engaged actively and practically in place of traditional methods. It must not be forgotten that these applications will be reflected in students' professional life in the future. (see Kabapinar, 2008, 328; Tuncel, 2019, 351).

2- Teacher candidates must be taught how to use primary sources with different activities for gaining skills (See. Dönmez \& Altıkulaç, 2014, 939). They should be even assigned research tasks based on using evidence to develop their different thinking skills. These studies will not only make contributions to their critical thinking skills (See. Avcı Akçalı, 2019, 243) but also to create models that they will apply in their professional life as a teacher. 


\section{Giriş}

Tarih disiplininin uygulaması, tarihsel kaynaklar ve kanıtlarla başlar ve tarihçilerin yararlanabileceği kaynaklar ise uçsuz bucaksız genişliktedir. Geçmişle ilgili yaklaşımlar ve kaynakların doğası değişse de tarihçiler onlarsız hiçbir iddiada bulunamazlar (Black \& MacRaild, 2016, s.77). Kısacası tarihçiler, geçmişin bilgisini oluştururken, bu bilgileri kaynaklarla kantlamak mecburiyetindedir (Yalı \& Şimşek, 2019, 22). Tarihsel kaynaklar, geçmişte gerçekleşmiş olaylardan ve insanların faaliyetlerinden geriye kalan, bugüne ulaşan izlerdir. Tarihçi bu izlerden hareketle geçmişi yeniden inşa eder. Tarihsel kaynaklar günümüzde 19. yüzyıldaki gibi kutsanmıyor, ama tarihi olayların anlaşılmasında, açıklanmasında, ciddi bir tarih araştırmasının ortaya çıkmasında yine de olmazsa olmaz bir faktör olarak rol oynamaya devam etmektedir (Acun, 2011, 149). Bu kaynaklar içinde "olayın geçtiği zaman, mekân ve şahıs olarak içinde yer alan veya en azından yakınında bulunan, içindeki bilgiler bakımından aracısız, doğrudan bilgi veren” birinci el kaynaklar önceliklidir (Tuş, 2015, 234-235). Tarihçilerin tarihsel kaynakların kapsamından ve tarihçilerin bunları düzenleme yöntemlerinden haberdar olmaları büyük bir önem taşımaktadır (Black \& MacRaild, 2016, s.77). Bu yüzden tarihçi adaylarının lisans ve lisansüstü dersleri yoluyla eğitimlerinde birinci el kaynakların tercüme edilmesi, yorumlanması, güçlü ve zayıf yönlerinin değerlendirilmesi, barındırdığı problemler üzerinde durulması gerekmektedir (Acun, 2011, 123). Kaynaklar ya da kanitlar günümüzde sadece tarih yazımının ve tarihçi adayının eğitiminin değil, aynı zamanda ilköğretim ve ortaöğretim okullarında tarih öğretiminin ve dolayısıyla tarih öğretmen adayı eğitiminin de önemli bir unsuru haline gelmiştir. Bu nedenden dolayı okullarda kaynakların/kanıtların kullanımına yönelik kanıt temelli öğrenme kavramı ortaya çıkmıştır. Kanıt temelli öğrenme, öğrencilerin küçük birer tarihçiler gibi birinci ve ikinci el farklı kaynakları/kanıtları kullanma ve sorgulama yoluyla bir takım düşünce becerilerini kazandığı zihinsel etkinlikler olarak tanımlanabilir (Alabaş, 2007, s. 9). Tarih öğretiminde kaynak/kanıtın gündeme gelmesi, daha eskiye dayanmakla birlikte esas olarak 1970'li yıllarda İngiltere' de gelişen yeni tarih anlayışı ile birlikte olmuştur (Bkz. Sylvester, 1997, s.12-17; Kabapınar, 2003, 40-41; 2014, 251-252; 2019, 29-30; Osborne, 2003; Keating \& Sheldon, 2011, 7-11; Dinç, 2014, 79-80). Bu anlayış çerçevesinde tarih derslerinin öğrenciyi edilgen bir konuma indirgeyen ezber yapısı sorgulanmış ve derslerde tarih metodolojisinin tanıtılması ve kanıtın kullanımı yoluyla öğrencilere tarihçilerin araştırma, analiz ve yorumlama gibi çalışma sürecine ilişkin deneyim ve becerilerin kazandırılmasına önem verilmiştir. Bu gelişmeler daha sonra dünyadaki farklı eğitim sistemlerini de etkilemiştir (Kabapınar, 2014, 251-252). Türkiye'de de yapılandırmacı eğitime geçişle birlikte 2004 yılından itibaren sosyal bilgiler dersi tarih konularında, 2007 yılından itibaren de tarih dersi konularında kanıt kullanımı önemli hale gelmiştir (Doğan, 2007,112-117). 2007 tarihli tarih dersi programında dersin amaçları arasında öğrencilerin "tarih araştırması yaparken tarih biliminin yöntem ve tekniklerini, kavramlarını ve tarihçi becerilerini doğru kullanmalarını sağlama" amacı yer almıştır. Programda tarihsel düşünme becerilerine de yer verilmiştir (MEB, 2007, 4, 10). Yine 2018'de yürürlüğe giren ve halen kullanılmakta olan tarih dersi programının amaçları (9., 11. ve 12. maddeler) (Bkz. MEB, 2018, s. 12) ve öğrencilere kazandırılması düşünülen alana özgü beceriler, yani tarih biliminin doğası ve tarihçilerin çalışma yöntemlerine dayanan beceriler (Bkz. MEB, 2018, 13-17) kaynak/kanıt kullanımını gerekli kılmaktadır.

İlköğretim ve ortaöğretim düzeyinde, tarih öğretimi sürecinde kaynakları etkinliklerle bütünleştirerek ele almaları beklenen öğretmen adaylarının, bu hususa yönelik yeterli düzeyde eğitim almaları gerekmektedir (Dilek \& Yapıc1, 2008, 343). Bu eğitimin ihmali, öğretmenlerin derslerinde kaynakları kullanmaları hususunda yaşadıkları önemli bir engeli teşkil etmektedir (Doğan \& Dinç, 2007, 218). Kanıt kullanımı konusunda genellikle ilköğretim sosyal bilgiler ve ortaöğretim tarih dersleri düzeyinde araştırmalar yapılmıştır (Bkz. Balkaya, 2002; Keleş, Ata \& Köksal, 2006; Doğan, 2008; Iş̧1k, 2008a; Işık, 2008b; N. Doğan, 2008; Çulha Özbaş, 2010; Çıdaçı, 2015; Bilgiç, 2018; Yetiş, 2018; Çiftarslan, 2019; Şener, 2019). Öğretmen adaylarının eğitiminde kanıt uygulamalarının yeri ve önemi ile kanıt uygulamalarına yer verilme duruma yönelik çalışmaların sayısı ise henüz sınırlıdır. Literatürde Dilek ve Yapıc1 (2008) tarafından kaynak temelli öğrenmeye yönelik oluşturulmuş sınavlar ile tarih öğretmen adaylarının tarihsel anlama ve yorumlama becerilerini tespit etme; Dönmez ve Altıkulaç (2014) tarafindan sosyal bilgiler öğretmen 
adaylarının TC İnkılâp Tarihi ve Atatürkçülük dersinde tarihsel kaynakların kullanımına yönelik görüşlerini ortaya koyma; Kiriş Avaroğulları ve Görgen (2014) tarafından tarih öğretmen adaylarının bir akademik tarihçinin tarihsel metinlerinde kullandığı yazma metodolojilerini kullanıp kullanamadıklarını ortaya koyma; Kaya (2015) tarafından tarih öğretmen adayları ile gerçekleştirilen kaynaklara dayalı öğretim uygulamalarında karşılaşılan sorunları nedenleriyle belirleme ve çözüm önerileri getirme; Avc1 Akçalı (2019) tarafından birinci el tarihi kaynakların eleştirel analizi yoluyla tarih öğretmen adaylarının eleştirel düşünme becerilerinin geliştirilmesi amacıyla yapılan çalışmalara rastlanmaktadır.

Literatürde görülen bu sınırlılık durumu ise bizleri bu alanda çalışma yapmaya teşvik etmiştir. Gibson'un (2014, 222) dediği gibi; "öğretmen eğitimcileri olarak, öğretmen adaylarının ileride tarihi ögretirken tarihsel kanıtları kullanmalarını ciddi bir şekilde ümit ediyorsak bunun olmasını engelleyen faktörleri ele alma konusunda gerçekçi olmalıyız. Bu görev öğretmen adaylarının tarihi öğretirken tarihsel kanıtları kullanmaya hazırlıklarını gelişstirmek için bazı önemli düşünceleri gerektirmektedir. Öğretmen adaylarının tarihi öğretirken değişik kaynaklardan edinilen kanıtları kullanmanın değerini anlayabilmeleri için, onlara kanıt kullanmanın yararlarını ve sinırlılıklarını anlamalarına yardımcı olacak etkinlikler sunulmalıdır. Çünkü öğretmenler tarihsel kanıt kullanılarak gerçekleştirilen tarih öğretiminin öğretim programına veya öğretim yöntemlerine uygun olmadığını düşünürlerse, bundan vazgeçeceklerdir".

$\mathrm{Bu}$ çalışmanın amac1; lisans programlarında yer alan tarih derslerinde birinci el kaynakların kullanım durumunu tespit etmektir. Bir yönüyle de öğretmen adaylarının lisans seviyesinde almış oldukları tarih eğitiminin, ortaöğretim tarih derslerinde birinci el kaynak kullanımı için yeterli olup olmadığını ortaya koymayı amaçlamaktadır. Bu sebeple öğretmen adayı yetiştirme sürecinde birinci el kaynak kullanma durumuna odaklanılmıştır. Araştırmada şu sorulara cevap aranmıştır:

1. Öğretim üyelerinin derslerinde birinci el kaynakları kullanma durumları hakkındaki görüşleri nelerdir?

2. Öğretim üyelerinin derslerinde birinci el kaynakları kullanma sıklıkları hakkındaki görüşleri nelerdir?

3. Öğretim üyelerinin derslerinde birinci el kaynakları kullanma amaçları hakkındaki görüşleri nelerdir?

4. Öğretim üyelerinin derslerinde birinci el kaynakları kullanma biçimleri hakkındaki görüşleri nelerdir?

5. Öğrencilerin lisans eğitimlerinde aldıkları derslerde birinci el kaynakların kullanım durumları hakkındaki görüşleri nelerdir?

6. Öğrencilerin lisans eğitimlerinde aldıkları derslerde birinci el kaynakların kullanım sıklıkları hakkındaki görüşleri nelerdir?

7. Öğrencilerin lisans eğitimlerinde aldıkları derslerde birinci el kaynakların kullanım biçimleri hakkındaki görüşleri nelerdir?

8. Öğrencilerin birinci el kaynakların kullanımına dair eğitim alma durumları hakkındaki görüşleri nelerdir?

9. Öğrencilerin birinci el kaynakların kullanımına dair eğitim alma biçimleri hakkındaki görüşleri nelerdir?

\section{Yöntem}

\section{Araştırma Modeli}

Lisans programlarında yer alan tarih derslerinde birinci el kaynakların kullanım durumunu tespit etmeyi amaçlayan bu çalışmada nitel veri toplama yöntem ve araçları benimsenmiştir. Nitel araştırmalar; insanların 
deneyimlerini nasıl anlamlandırdıklarını ve yorumladıklarını onların penceresinden inceleyen, tümevarımsal bir sürecin izlendiği bir araştırma türüdür. Araştırmacının verilerin toplanması ve analizinde etkin olduğu bu araştırmalar ile zengin betimlemeler ortaya konmaktadır. Çalışma deseni ve sürecinin genelde esnek ve koşullara duyarlı olması, amaçlı örneklemin seçilmesi, araştırmacının zamanının önemli bir kısmını doğal ortamlarda geçirmesi ve katılımcılarla yakın temasta olması bu araştırma türünün özelliklerindendir (Merriam, 2013, 14-16). Araştırmada betimsel tarama modeli benimsenmiştir. Betimsel tarama modeliyle geçmişte veya şimdi var olan bir durumun olduğu şekliyle betimlenmesi amaçlanır. Bu var olan durum değiştirilmeden, etki yapılmadan kendi koşulları içerisinde ve olduğu gibi ele alınır (Karasar, 1999, 77).

\section{Çalışma Grubu}

Çalışmada katılımcılar amaçlı örneklem yöntemlerinden birisi olan kolay ulaşılabilir durum örneklemesi yoluyla seçilmiştir. Nitel araştırmalarda yaygın biçimde tercih edilen kolay ulaşılabilir durum örneklemesi, çalışmalara hız ve pratiklik sağlar (Yıldırım \& Şimşek, 2013, 141). Araştırmanın çalışma grubu 2016-2017 akademik yılında Atatürk Üniversitesi Kazım Karabekir Eğitim Fakültesi’nde görevli 9, Atatürk Üniversitesi Edebiyat Fakültesi'nde görevli 16, Erzurum Teknik Üniversitesi Edebiyat Fakültesi'nde görevli 2 olmak üzere tarih derslerini yürüten toplam 27 öğretim üyesi ile Atatürk Üniversitesi Kazım Karabekir Eğitim Fakültesi Tarih Eğitimi Anabilim Dalı 4. sınıfta okuyan 20, Edebiyat Fakültesi Tarih Bölümü 4. sınıfta okuyan 30, Erzurum Teknik Üniversitesi Edebiyat Fakültesi Tarih Bölümü 4. sinıfta okuyan 20 olmak üzere toplam 70 öğrenciden oluşmaktadır. Araştırmaya tarih öğretmenliği anabilim dalı dışında tarih bölümlerinin de katılmasının nedeni, bölüm öğrencilerinin de kendilerine tanınan formasyon eğitimi sayesinde öğretmenliğe başvurabilme imkânlarının olmasıdır.

\section{Veri Toplama Araçları}

Verilerin toplanmasında, yarı yapılandırılmış görüşme formu ve açık uçlu anket formu birlikte kullanılmıştır. Araştırmada öğretim üyelerinin görüşlerini belirlemek için araştırmacı tarafından geliştirilmiş yarı yapılandırılmış görüşme formu kullanılmıştır. Görüşme formu kullanılmadan önce hazırlanan sorular; alanında uzman iki ögretim üyesi tarafından incelenmiş, onlarca önerilen düzeltmeler yapılmış ve ardından araştırmacı tarafindan pilot uygulaması yapılmıştır. Pilot uygulama sonrası soruların anlaşılır, açık ve net olduğu belirlenmiş; bazı değişikliklerin yapılması konusunda fikir birliğine varılarak sorular son şeklini almıştır. Görüşme formundaki sorularla öğretim üyelerinin derslerinde birinci el kaynakları kullanma durumları ve biçimleri ile bu kaynakları kullanma amaçları ortaya konulmak istenmiştir. Görüşmelerde bireylerden daha sağlıklı cevaplar alabilmek için gönüllülük esası gözetilmiştir. Bu bağlamda etik kurallara uygun olarak gönüllü katılım formu hazırlanmıştır. Öğretim üyeleri ile yapılan görüşmeler, 27 Mart 2017 tarihinde başlamış, 24 Mayıs 2017 tarihinde son bulmuştur. Yapılan görüşmelerde öğretim üyelerine kimlik bilgilerinin gizli tutulacă̆ üyelerinin bazılarının ses kaydına izin vermemesi nedeniyle not alma şeklinde yürütülmüştür. Öğretim üyeleri ile yapılan görüşmelerde süre sınırlamasına gidilmemiştir. Görüşmelerin kayıtları bilgisayarda Word programına aktarılıp, çıktısı alınarak öğretim üyelerinin kendilerine okutulmuş ve onayları alınmıştır.

Araştırmada veri toplama araçlarını çeşitlendirmek, daha güvenilir bilgiye ulaşmak ve öğretim üyelerinin vermiş oldukları cevapları teyit etmek amacıyla açık uçlu anket formu kullanılarak öğrencilerin görüşleri belirlenmiştir. Açık uçlu anket formundaki sorularla ögrencilerin derslerinde birinci el kaynakların kullanılma durumları ve biçimleri ile öğrencilerin birinci el kaynakların kullanımına dair eğitim alma durumları ve bu eğitimin biçimleri ortaya konulmak istenmiştir. Anket formunun uygulaması, öğretim üyesinden izin istenerek dersin ilk 25 dakikası içerisinde araştırmacı tarafından gerçekleştirilmiştir. Anket formunun sınıflarda uygulanabilmesi için Eğitim Bilimleri Enstitüsü Müdürlüğü’nden gerekli izinler alınmıştır. 


\section{Veri Analizi}

Yarı yapılandırılmış görüşme formu ve açık uçlu anket formundan elde edilen veriler içerik analizi ile çözümlenmiştir. Bu analiz türünde "birbirine benzeyen verileri belirli kavramlar ve temalar çerçevesinde bir araya getirmek ve bunlar okuyucunun anlayabileceği bir biçimde düzenleyerek yorumlamak" esastır (Yıldırım \& Şimşek, 2013, s. 259). Veriler araştırmacı tarafından incelenmiş, kodlar ve kategoriler oluşturulmuştur. Kod "veriler arasında yer alan anlamlı bölümlere verilen anlam" iken kategori ise "kodların birbiri ile belirli bir tema altında sınıflandırılması işlemi”"dir (Yıldırım \& Şimşek, 2013, 260). Oluşturulan kodlar arasında benzerlik gösterenler uygun kategori altında toplanmış ve tablolar halinde verilmiştir. $\mathrm{Bu}$ işlem hem araştırmacı hem de bir alan uzmanı tarafindan yapılmış, bulgular kodlayıcı güvenirliğinin sağlaması amacıyla birbiri ile kıyaslanmıştır. Araştırmacı ve alan uzmanı tarafından incelenmiş olan kategoriler yeniden değerlendirilip tablolaştırılmıştır. Tablolar öğretim üyelerinin ve öğrencilerin görüşlerinin frekans ve yüzdeleri ile sunulmuştur. Bulgularda katılımcılardan doğrudan alıntılara yer verilmiş, bu alıntılarda anlam bütünlügünü bozacak kelime ya da devrik cümlelerin düzeltilmesi dışında başka hiç bir değişiklik yapılmamıştır (bkz. Güler, Halıcıoğlu \& Taşğın, 2013: 158). Alıntılarda öğretim üyelerinin ve öğrencilerin gerçek isimleri yerine E1, F1, T1 gibi kodlar kullanılmıştır.

\section{Geçerlik ve Güvenirlik}

Geçerlik ve güvenirlik, hangi araştırma türü olursa olsun kavramsal çerçevenin oluşturulmasından verilerin toplanmasına, analiz edilmesine, yorumlanmasına ve bulguların sunulmasına kadar tüm aşamalarla ilgili önemli kaygılardır (Merriam, 2013, 200). Bu araştırmada öncelikle ilgili literatür taraması yapılmış, konu üzerinde benzer çalışmalar yapan araştırmacıların bulguları değerlendirilmiştir. Araştırmacı çalışmasında görüşmeleri ve açık uçlu anket uygulamalarını bizzat kendisi gerçekleştirmiş, çalışma grubu ile etkileşim halinde bulunmuştur. Çalışmada geçerlik ve güvenirliği artırmak için şunlara dikkat edilmiştir: Verilerin toplanmasında kaynak ve yöntem açısından çeşitleme yoluna gidilmiştir. Öncelikle farklı fakültelerde görev yapan öğretim üyeleri ve bu farklı fakültelerde öğrenimlerini sürdüren son sınıf öğrencileri çalışma grubu olarak belirlenmiştir. Bu kapsamda öğretim üyeleri ile yapılan görüşmelerde derinlemesine veriler toplanmış ve elde edilen bu verileri teyit etmek amacıyla öğrencilerden açık uçlu anket formu ile veriler toplanmıştır. Çalışmada kullanılan görüşme ve açık uçlu anket formu soruları alanında uzman kişilere gösterilmiş ve onlardan bu soruları anlaşılırlık, açıklık ve araştırmanın amacına uygunluk açısından değerlendirmeleri istenmiştir. Uzman kişilerin fikirleri çerçevesinde sorular son şeklini alıp pilot uygulaması yapılmıştır. Görüşmelerin ve açık uçlu anket formunun uygulanmasında katılımcıların gönüllülük onayı alınmıştır. Görüşmeler sonrasında öğretim üyelerinin vermiş oldukları cevaplar Word programına aktarılmış, çıktıları alınarak onlara gösterilmiş ve onayları alınmıştır. Verilerin analizinde alanında uzman kişinin kodlamaları ile karşılaştırmalar yapılmış ve kodlarda uyum sağlanmaya çalışılmıştır. Elde edilen veriler, tablolar halinde ve araştırmacının yorumu olmadan katılımcılardan aynen alıntılar ile sunulmuştur. Çalışmada nispeten katılımcıların hepsinden alıntılar verilmeye çalışı1mıştır. Son olarak araştırmacının topladığı tüm veriler ulaşılan sonuçların teyit edilebilmesi adına saklanmıştır (Bkz. Yıldırım \& Şimşek, 2013, 289-308).

\section{Bulgular ve Yorumlar}

$\mathrm{Bu}$ bölümde katılımcıların görüşme ve açık uçlu anket formlarında yer alan sorulara verdikleri cevaplardan elde edilen bulgular, yüzde ve frekanslarıyla birlikte tablolar halinde sunulmuş ve açıklanmıştır. Öğretim üyelerinin ve öğrencilerin bazı sorularla ilgili birden fazla görüş belirtmesinden dolayı, bu sorulara yönelik hazırlanan tablolarda (Tablo 3, 4, 7 ve 9) frekans değerleri katılımcı sayısını değil; o soruyla ilgili katılımcıların belirtmiş oldukları görüş sayısını ifade etmektedir. Burada belirtilmesi gereken bir başka husus ise birinci el kaynaklar konusunda tek cevabı olan sorular hariç, diğer sorulara yönelik katılımcılar tarafindan sadece bir kez dile getirilen görüşlerin diğer kategorisine alınmasıdır. Diğer kategorisindeki görüşlerin neler olduğu ise tabloların altında açıklanmıştır. 
Öğretim Üyeleri İle Yapılan Görüşmelerden Elde Edilen Bulgular ve Yorumları

Öğretim üyelerinin derslerinde birinci el kaynakları kullanma durumları hakkındaki görüşleri

Görüşme yapılan 27 tarih öğretim üyesine ilk olarak derslerinde birinci el kaynakları kullanma durumları sorulmuş, elde edilen bulgular, frekans ve yüzdeleri ile Tablo 1'de verilmiştir.

Tablo 1. Öğretim Üyelerinin Derslerinde Birinci Eı Kaynakları Kullanma Durumları

\begin{tabular}{lcc}
\hline Görüsşler & f & \% \\
\hline Kullananlar & 23 & 85 \\
Kullanmayanlar & 4 & 15 \\
\hline Toplam & 27 & 100 \\
\hline
\end{tabular}

Tablo 1'de görüldüğü üzere öğretim üyelerinden 23'ü derslerinde birinci el kaynakları kullandıklarını, 4'ü ise kullanmadıklarını ifade etmişlerdir. Öğretim üyeleri derslerinde en çok arşiv belgelerini daha sonra sırasıyla kronikleri, resim ve fotoğrafları ve hatıratları kullandıklarını dile getirmişlerdir. Soruya olumsuz cevap veren 4 öğretim üyesi, birinci el kaynakları kullanmama nedenlerini; sınıf içindeki teknolojik donanımların yetersiz ya da bozuk olması, dersin konusuna uygun birinci el kaynak bulunamaması, birinci el kaynak kullanımının öğrenci seviyesine uygun olmaması, kaynak kullanımının eğitim sistemimiz için pek uygun olmaması, derse donanımlı ve hazırlıklı gelinememesi ve öğrencilerin yabancı dildeki birinci el kaynakları anlamada zorluklar yaşaması olarak göstermişılerdir.

\section{Öğretim üyelerinin derslerinde birinci el kaynakları kullanma sıklıkları hakkındaki görüşleri}

Derslerinde birinci el kaynakları kullandıklarını ifade eden 23 öğretim üyesine bu kaynakları ne sıklıkla kullandıkları sorulmuş; elde edilen bulgular, frekans ve yüzdeleri ile Tablo 2' de verilmiştir.

Tablo 2. Öğretim Üyelerinin Derslerinde Birinci Eı Kaynakları Kullanma Sıklıkları

\begin{tabular}{lcc}
\hline Görüşler & f & \% \\
\hline Dersin konusuna göre yeri geldikçe kullanma & 15 & 65 \\
Genelde kullanma & 6 & 26 \\
Temin edilebilen kaynaklar ölçüsünde kullanma & 2 & 9 \\
\hline Toplam & 23 & 100 \\
\hline
\end{tabular}

Tablo 2'den anlaşılacağı üzere öğretim üyelerinin derslerinde birinci el kaynakları kullanım sıklıkları sırasıyla dersin konusuna göre yeri gedikçe, her ders için genelde ve temin edilebildiği ölçüde şeklindedir. Konu hakkındaki görüşlerden bazı alıntılar aşağıda sunulmuştur:

Katılımc1 16 “...Her ders ve konu bahsettiğim belgeleri kullanmaya uygun değil. Mesela...Mahkeme Kayıtlarını daha fazla kullanıyorum. Bu durumu biraz da çalışma alanıma daha yakın olması etkiliyor. Konularım da biraz daha mahkeme kayıtlarına dayalı olduğu için yeri geldikçe kullanıyorum."

Katılımc1 24 “... Birinci el kaynakları her derste kullanıyorum. Ayrica her derste her konu ile ilgili elimizdeki mevcut olan, o konu ile ilgili orijinal belgeleri, gazete haberlerini, hatıralardaki bilgileri ögrencilerimize aktarıyoruz veya öğrencilerimize seminer ödevi vererek birinci el kaynaklara yönlendiriyoruz."

Katılımc1 5 "Her derste kullanamazsınız. Zaman kaybı olur. Konunun önemine göre kullanıyorum."

Katılımc1 10 “Temin edilebildiğim kadarlyla kullanıyorum”. 


\section{Öğretim üyelerinin derslerinde birinci el kaynakları kullanma amaçları hakkındaki görüşleri}

Derslerinde birinci el kaynakları kullandığını söyleyen 23 tarih öğretim üyesine, bu kaynakları kullanma amaçları sorulmuş; elde edilen bulgular, frekans ve yüzdeleri ile aşağıda Tablo 3 'te verilmiştir.

Tablo 3. Öğretim Üyelerinin Derslerinde Birinci Eı Kaynakları Kullanma Amaçları

\begin{tabular}{lcc}
\hline Görüşler & f & \% \\
\hline Öğrencilere anlattı̆̆ı bilgileri nereden aldığını göstermek, bilgilerini temellendirmek & 11 & 22 \\
Öğrencilere kaynakların niteliğini ve nasıl kullanılacağını göstermek & 10 & 20 \\
Öğrencilere doğru ve en güvenilir bilgiyi sunmak & 8 & 16 \\
Öğrencileri akademik hayata hazırlamak & 6 & 12 \\
Öğrencilerin derse ilgisini çekmek & 3 & 6 \\
Bilgilerin benzerliklerini ve farklılıklarını karşılaştırmak & 3 & 6 \\
Bilgiyi göstererek, somutlaştırarak öğrenmeyi sağlamak & 2 & 4 \\
Diğger & 7 & 14 \\
\hline Toplam & 50 & 100 \\
\hline
\end{tabular}

Tablo 3'ten anlaşılacağı üzere öğretim üyeleri derslerinde birinci el kaynakları kullanmalarındaki amaçlar noktasında en çok anlattıkları bilgileri nereden aldıklarını öğrencilere göstermek ve anlattıklarını bilimsel bilgilerle temellendirmek görüşünü dile getirmişlerdir. Öğretim üyeleri özellikle anlatılan bilgilerinin asıl kaynağının ne olduğuna dair öğrencilerin kafalarında soru işaretleri oluştuğunu belirterek bu soru işaretlerini gidermek amacıyla kaynakları kullandıklarını söylemişlerdir. Öğretim üyelerinin üzerinde durdukları ikinci görüş ise öğrencilere belgelerin ve kanıtların birebir tanıtılması ve nasıl kullanılacaklarının gösterilmesi olmuştur. Öğretim üyelerinin birinci el kaynakları kullanmalarının bir başka amacı da öğrencilere doğru ve güvenilir bilgileri aktarmaktır. Dile getirilen bir başka görüş ise öğrencileri bilginin doğruluğunu araştırmaya sevk edip onları kaynaklara aşina kılarak akademik hayata hazırlamaktır. Birinci el kaynakların kullanımıyla ilgili olarak daha az sıklıkla belirtilen amaçlar ise öğrencilerin derse ilgisini çekmek, bilgilerin benzerliklerini ve farklılıklarını karşılaştırmak ve somut öğrenmeyi sağlamaktır. Bu son görüşte tarih derslerinin sözel ve soyut olmasına, deney yapma şansı vermemesine değinen öğretim üyeleri, bu durumun öğrencilerde başarıyı düşürdüğünü ve olayların anlaşılmasını zorlaştırdığını belirterek birinci el kaynakların dersi somutlaştıracağını ve bu sorunların çözümüne katkı sağlayacağını ifade etmişlerdir.

Diğer kategorisinde toplanan görüşler ise Osmanlı Türkçesi hakkındaki yanlış kanaatleri düzeltmek, geçmişteki insanların dünyaya bakışını kavratabilmek, kaynakları öğrenciye sevdirebilmek, bilimsel güvenilirliği sağlamak, öğrencilere bilgiyi kendilerine göre yorumlama ve tenkit edebilme yeteneğini kazandırmak, kaynaklar aracılığıyla öğrencilerin tarihe bakış açılarını değiştirebilmek, tarih derslerinin birinci el kaynak kullanımını zorunlu kılması şeklindedir. Bu soruya iki öğretim üyesi ise cevap vermemiştir. Konu hakkındaki görüşlerden bazı alıntılar aşağıda sunulmuştur:

Katılımc1 20 "Öğrencilerin "hocam tamam siz bunları aktarlyorsunuz veya derste kullanmak için materyal olarak veriyorsunuz ama bu hangi kaynakta yer allyor" diye sorular sormaması açısından kullanıyorum. Buradaki kitaplar bunu nereden almışlar? Herhangi bir şekilde A kaynă̆ ile B kaynă̆ arasında fark var mı? Bütün Osmanlı kaynakları veya yabancı kaynaklar aynı paralellikte mi arz ediyor? Bunları göstermek amacılla kullanıyorum. Hem bilgilerimi temellendirmek hem öğrenciyi ikna etmek için diyebiliriz..."

Katılımc1 14 “...Öğrenciye işlenen konunun temel bilgilerini göstermek amactyla kullaniyoruz. Tarih yazıyla başlar. (...) Tarihin temel kaynağı yazılı eserlerdir. Yazılı olmayan bulgular tarihin çalışma sahasına girmez, arkeolojinin sahasına girer. Dolayısıyla bizim kaynağımız laboratuvarlarda deney yapamayacağımız için yazılardır. Biz de çocuklara konularla ilgili bilgilerin hangi kaynakta olduğunu söylemek amacıla bunları kullanıyoruz. Kafalarındaki sorular bu kaynaklardan bulabileceklerini söylüyoruz." 
Katılımc 17 “...Zaman zaman yapmaları gereken araştırmalarda bunları nasıl kullanacakları noktasında bir bilgi vermek, değerlendirmelerini nasıl yapacaklarına dair bir bilgi aktarımı yapmak ve mutlaka birinci elden kaynak varsa olayı birinci elden kaynaklara dayandırarak objektif bir şekilde bir disiplin kazanmalarını sağlamak amacındayız."

Katılımc 10 "Hem öğrencilere bu kaynakları tanıtmak, hem de doğru ve güvenilir bilgiyi vermek için...(kullanıyorum).”

Katılımc1 22 "Bahsettiğimiz gibi öğrencilerde bir farkındalı oluşturmak, kaynakların genel anlamda neler olduğu, nasıl kullanılması gerektiği bilgisini vermek ve içlerindeki o yazı şeklini, ifade biçimini, ifade tarzını, tarihe bakışını onların anlayabilmeleri amacıyla kullanıyorum."

Katılımc1 27 “...Ders için amacım ögrencilere daha faydalı olabilmek ve kaynă̆ı öğrenciye tanıtmak, onlara göstermektir. Bahsettiğimiz o akademik yaşama öğrenciyi hazırlamak ve ögrrenci mezun olduğu zaman hiç olmazsa belgeyi görmüş, mümkünse ĕger dokunabilmiş olsun istiyoruz. Görmeden bu fakülteden mezun olsun istemiyoruz..."

Katılımc1 6 “...belli kaynaklara atıfta bulunarak bu eser böyle anlatıyor, başka eser bu bilgiyi böyle veriyor diye ikinci el kaynakları da işin içine dâhil ederek ögrenciyi bilgilendiriyoruz. Tabi burada bilimsel bilgi ve mutlak bilgi faktörü de karşımıza çıklyor. Mesela...derslerimde öğrencilerimizle Göktürk Kitabelerinin kritiğini yapabiliyoruz. Yine söylediğim gibi kaynaklara atıf yaparak mesela Yahya Akyüz şu eserinde bunu böyle belirtmiş, bir başka yazar da aynı konu üzerinde böyle değinmiş diyerek karşılaştırma yapabiliyoruz."

Katılımc 2 “...Kullanım amacımız ögrencinin birebir o materyali tanıması, bilmesi, ögrenmesi, ne işe yaradı̆̆ını görmesi. Çünkü diğer türlü soyut olur. Bu somutlaştırıyor. Mesela fermandan bahsediyorsun. Ĕ̆er o fermanın şeklini şemalini göstermezsen öğrencinin kafasında ferman soyut bir kavram olarak kallyor. Yansıda gösterdiğiniz zaman o tuğrasıyla, şekliyle, yazı çeşidi ile neyin ferman, neyin Hatt-ı Hümayun ya da neyin hüküm olduğunu anlıyor... Burada duyulara hitap ediliyor. Sadece kulağa değil, aynı zamanda göze hitap ediliyor..."

\section{Öğretim üyelerinin derslerinde birinci el kaynakları kullanma biçimleri hakkındaki görüşleri}

Derslerinde birinci el kaynakları kullandığını söyleyen 23 öğretim üyesine, bu kaynakları nasıl kullandıkları sorulmuş; elde edilen bulgular, frekans ve yüzdeleri ile Tablo 4 'te verilmiştir.

Tablo 4. Öğretim Üyelerinin Derslerinde Birinci EI Kaynakları Kullanma Biçimleri

\begin{tabular}{lcc}
\hline Görüşler & f & \% \\
\hline Projeksiyon yardımıyla birinci el kaynakların görsellerini gösterme ve tanıtma & 21 & 33 \\
Farklı tarafların kaynaklarını birlikte kullanma, kaynak karşılaştırması yapma & 11 & 17 \\
$\begin{array}{l}\text { Öğrencilere dersle ilgili kaynakların neler olduğunu, bu kaynakların niteliğini, } \\
\text { nerede bulunabileceğini ve nasıl kullanılması gerektiğini anlatma }\end{array}$ & 8 & 13 \\
$\begin{array}{l}\text { Öğrencilere, kaynakları sınıfa götürmeden sözel olarak aktarma ve örnekler } \\
\text { verme }\end{array}$ & 6 & 9 \\
Öğrencilere birinci el kaynak niteliğindeki tarihi film ve belgeselleri izletme & 4 & 6 \\
$\begin{array}{l}\text { Birinci el kaynakların fotokopilerini ya da dönem gazetelerinin örneklerini } \\
\text { öğrencilere verip onların incelemelerini sağlama }\end{array}$ & 3 & 5 \\
$\begin{array}{l}\text { Kaynaktaki bilgilerin kesin ve doğru olup olmadı̆ı̆ı tartışma } \\
\text { Birinci el kaynak niteliğindeki haritaları gösterip dersi harita üzerinden yürütme }\end{array}$ & 3 & 5 \\
Diğer & 2 & 3 \\
\hline Toplam & 6 & 9 \\
\hline
\end{tabular}


Tablo 4'te görüldüğg̈ gibi öğretim üyelerinin çoğu derslerinde birinci el kaynakları, bu kaynakların görsellerini projeksiyon cihazı yardımıyla öğrencilere gösterip, bu görseller üzerinden örnekler verme biçiminde kullandıklarını ifade etmişlerdir. Böyle bir yolu tercih etmelerinin nedenini ise projeksiyon cihazının kullanımının kolay ve müfredatı yetiştirmek açısından zaman kazandırıcı olması şeklinde açıklamışlardır. Ayrıca bazı öğretim üyeleri birinci el kaynakların görsellerinin öğrencilerin zihninde canlandırma işlevini gördüğünü, somutlaştırarak öğrenme yoluyla akılda kalıcılığı sağladığını ifade etmişlerdir. İkinci sırada yer alan görüş ise farklı görüşleri barındıran kaynakları ders süresince birlikte kullanarak, kaynak karşılaştırması yapmak olmuştur. Bu kullanım şeklinin hem doğru bilgiye ulaşmak için hem de objektifliği artırıp, kalıp düşünceleri aşındırmak, hatta yıkmak için tercih edildiği söylenmiştir. Özellikle hatırat gibi objektifliği tartışmalı olan birinci el kaynakların karşılaştırmalar yapılarak derslerde kullanılması gerektiği birçok öğretim üyesi tarafindan belirtilmiştir. Üçüncü sıradaki görüş ise öğrencilere kaynakları tanıtma, bu kaynakları nereden temin edebileceklerine ve nasıl kullanabileceklerine dair bilgiler sunma şeklindedir. Bazı ögretim üyeleri ise kaynakları sınıfa götürmenin zaman kaybına neden olduğunu, bu durum sebebiyle kaynaklardan sadece sözel olarak faydalandıklarını dile getirmişlerdir.

Öğretim üyelerinin bazıları ise birinci el kaynak niteliğini taşıyan film ya da belgesellerin öğrencilerin dikkatini daha çok çektiğini söyleyerek derslerini bu sunum araçları üzerinden işlediklerini belirtmişlerdir. Böylesi bir kullanımın hem dersi zevkli hale getirdiğini hem de karşılaştırmalı öğrenmeye imkân sağladığını ifade etmişlerdir. Bazı öğretim üyeleri de derslerinde birinci el kaynakların fotokopilerini ya da dönem gazetelerinin örneklerini incelemenin, birinci el kaynak niteliğindeki haritaları gösterip derslerini harita üzerinden yürütmenin daha zevkli olduğunu ve kalıcı öğrenme sağladığını dile getirmişlerdir. Tablo incelendiğinde bazı öğretim üyelerinin ise birinci el kaynakların güvenilirliğini ve içinde yer alan bilgilerin doğruluğunu tartışma yoluyla derslerini yürüttükleri görülmektedir.

Diğer kategorisinde toplanan görüşler ise öğrencileri birinci el kaynaklarla ilgili çalışmalara yönlendirme, anlatılanları destekleme ve kanıtlama, öğrencilerin kaynak hakkında varsa sorularını cevaplama, öğrencileri sınavlarda kaynak eser soruları ile karşı karşıya bırakma, öğrencilerin seviyesine uygun hale getirecek ön çalışmalar sunma, birinci el kaynağı başka materyallerle destekleyerek kullanma şeklindedir. Konu hakkındaki görüşlerden bazı alıntılar aşağıda sunulmuştur:

Katılımc1 25 “...Sinıflarda da genelde görsel malzeme olarak yeri geldikçe kullanıyoruz. Yani sinıflarda gösterdiğimiz materyallerin hepsi birinci elden kaynaklardır. Mesela bir yazıt (projeksiyonla) gösteriyoruz, sonradan yazıtın çevirisini gösteriyoruz. O çeviri ışığında konularımızı anlatıyoruz. Daha sonra alanında uzman kişilerin o konu hakkında değerlendirmelerini verip, bu kişilerin kitapları ışığında bilgilerimizi veriyoruz. (...) Mesela bazen ögrencilere mezar taşlarını gösteriyoruz. Türk Tarihi ile ilgili bağlantılı çok eski mezar taşları var. Bunların bağlantılarını öğrencilerimizle kuruyoruz. Mesela Türklerin Anadolu'ya gelişi 1071 olarak biliniyordu. Ama biz bunu birinci elden kaynaklar ışı̆̆ında MÖ. 8. yüzyıla götürüyoruz. Yani Kimmerler, İskitler dönemine. Biz hikayeci tarihi anlatarak Türkler Anadolu'ya 1071'den önce geldi demiyoruz. Birinci elden kaynaklarla bunu ispatlayıp öyle konuşuyoruz...”

Katılımc1 9 “... Mümkün mertebe konu ile ilgili yerli yabancı her türlü kaynă̆ı görmek isterim...Yani bir Yunan askerinin hatıratını verdiğimde, onun karşılı̆̆ olan Türk askerinin eserinden de bahsetmeyi kendimde zorunluluk hissederim. Amacım da mukayese yaptırmak..."

Katılımc1 3 “...Mesela Tarih ...Dergisini götürüyorum. Buradaki amacım cepheden gelen telgrafların kimler arasında yazıldığını, olayın nasıl aktarıldı̆̆ını öğrenciye göstermek. Mesela hatıratların karşılaştırmasını yapıyorum. Dönemin önemli aktörlerinin hatıratlarını çalıştırdığım Alan Çalışması derslerim olmuştur. Herkes istediği kişiyi alıp, hatıratlarını çalıştı. Burada hem hatırat çalışmayı ögreniyorlar hem de birinci el kaynağı nasıl kullanacaklarını öğreniyorlar. Böylelikle de önemini de kavrlyorlar..."

Katılımc1 10 “...Konu anlatımında şu kaynakta veya şu belgede bu bahis hakkında şöyle bilgiler bulunmaktadır deyip bilgiyi paylaşıyoruz.” 
Katılımc 27 “...20. yy başlarından itibaren filmlerin de görülmeye başlaması ile yakın tarihi bu filmlerden anlatma (sunma) yoluna da gidebiliyoruz. Tabi bunlar yeri geldikçe kullanılır. Öğrenciler üzerinde en etkili olan ise fotoğraflar ve filmlerdir. Öğrenci o fotoğrafi görünce meseleye daha vaklf oluyor ve çok daha fazla bilgiyi kssa sürede bir anda ögrenciye verebiliyorsun ..."

Katılımc 6 “...Mesela öğrencilerimle Herodot'tan pasajlar okuyoruz. Bunlar öğrencinin değerlendirmesini istiyorum. Öğrenci bazen bu belgeleri görünce bunları kesin bilgi olarak alıp kabul edebiliyor. Bunların tartışmasını yani belgelerin kesin bilgi olup olmadığını tartışıyoruz (...) Belgeleri özellikle ögrencilerime tanıtıp, çeviri yaptırıyorum. Yani sözel olarak belgeleri kullandı̆̆ımı söyleyebilirim. Derse girdiğimde ögrenciye kaynă̆ tanitıyorum, çevrilmesi gereken bir metin ise çevirisini yaptıktan sonra ögrencilerle belge üzerinde tartışıoruz."

Öğrencilere Uygulanan Açık Uçlu Anket Formundan Elde Edilen Bulgular ve Yorumları

Öğrencilerin lisans eğitimlerinde aldıkları derslerde birinci el kaynakların kullanım durumları hakkındaki görüşleri

Açık uçlu anket uygulanan toplam 70 öğrenciye lisans eğitimlerinde aldıkları derslerde birinci el kaynakların kullanım durumları sorulmuş, elde edilen bulgular, frekans ve yüzdeleri ile aşağıdaki Tablo 5 'te verilmiştir.

Tablo 5. Öğrencilerin Lisans Eğitimlerinde Aldıkları Derslerde Birinci Eı Kaynakların Kullanım Durumları

\begin{tabular}{lcc}
\hline Görüşler & f & \% \\
\hline Kullanılan & 47 & 67 \\
Kullanılmayan & 16 & 23 \\
Cevap vermeyenler & 7 & 10 \\
\hline Toplam & 70 & 100 \\
\hline
\end{tabular}

Tablo 5'de görüldüğü gibi öğrencilerin çoğunluğu (47 öğrenci) derslerinde birinci el kaynakların kullanıldığını söylerken sadece 16 öğrenci bu kaynakların kullanılmadığını ifade etmiştir. Bu durum öğretim üyelerinin verdikleri cevaplarla örtüşmektedir. Bu soruya yedi öğrenci ise cevap vermemiştir. Öğrenciler derslerinde en çok arşiv belgelerinin kullanıldığını belirtmişlerdir. Bunu sırasıyla kitaplar, vakanüvist tarihleri ve hatıralar izlemiştir.

\section{Öğrencilerin lisans eğitimlerinde aldıkları derslerde birinci el kaynakların kullanım sıklıkları hakkındaki görüş̧leri}

Katılımcı öğrencilere bu kaynakların ne sıklıkla kullanıldığı sorulmuş; elde edilen bulgular, frekans ve yüzdeleri ile aşağıdaki Tablo 6'da verilmiş̧tir.

Tablo 6. Öğrencilerin Lisans Eğitimlerinde Aldıkları Derslerde Birinci El Kaynakların Kullanım Sıklıkları

\begin{tabular}{lcc}
\hline Görüşler & f & \% \\
\hline Dersin akışına göre & 23 & 32 \\
Hemen hemen her derste & 11 & 15 \\
Nadiren & 11 & 15 \\
Dersin özelliğine göre & 5 & 7 \\
Epigrafi ve Paleografya derslerinde her ders & 2 & 3 \\
Cevap vermeyenler & 18 & 28 \\
\hline Toplam & 70 & 100 \\
\hline
\end{tabular}


Tablo 6'da görüldüğü gibi öğrenciler derslerinde birinci el kaynakların öncelikle dersin akışına göre kullanıldığını, daha sonra eşit oranda hemen hemen her derste ve nadiren kullanıldığını belirtmişlerdir. Dersin özelliğine göre birinci el kaynakların kullanıldığı da dile getirilen görüşler arasındadır. Öğrencilerden iki kişi ise Epigrafi ve Paleografya gibi derslerin birinci el kaynakların kullanımına daha uygun olduğunu belirterek sadece bu derslerde kaynakların kullanıldığını dile getirmişlerdir. Bu soruya toplamda 18 öğrenci cevap vermemiştir. Soruya cevap vermeyenlerin çoğunluğu derslerinde kaynak kullanılmadığını belirten öğrencilerdir. Konu hakkındaki görüşlerden bazı alıntılar ise aşağıda sunulmuştur:

Katılımcı F1 "Dersin akışına ve hocanın dersi işleyişine bağlı kullanılıyordu..."

Katılımc1 F6 "Çok sıklıkla. Gerçekten hemen hemen her derste konusuna göre derslerde adı geçen kitaptan bir örnek dahi olsa verildi."

Katılımc 19 "Ilgili derslerde dönem boyunca kullanıldı."

Katılımc1 T13 "İki ayda bir kullanılyyordu."

Katılımc1 T12 "Konunun işlenişine göre kullanılıyordu."

Katılımc1 T9 "Her derste kullanıldı. Kitap, makale, gazete, eski arşiv belgelerini okuduk.”

Katılımc1 T15 "Konunun ihtivasına göre kullanilıyordu."

Katılımc1 E12 "Çok fazla olmasa da derslerden derslere farklılık arz ediyordu. Dersin ve konunun içeriğine göre gerekli gördüğümüz noktalarda kullanıyorduk."

Kat1lımc1 F13 "Genel olarak bütün derslerde(kullanıld1)."

Öğrencilerin lisans eğitimlerinde aldıkları derslerde birinci el kaynakların kullanım biçimleri hakkındaki görüşleri

Katılımcı öğrencilere bu kaynakların derslerinde nasıl kullanıldığı sorulmuş, elde edilen bulgular, frekans ve yüzdeleri ile aşağıdaki Tablo 7'de verilmiştir.

Tablo 7. Öğrencilerin Lisans Eğitimlerinde Aldıkları Derslerde Birinci Eı Kaynakların Kullanım Biçimleri

\begin{tabular}{lcc}
\hline Görüșler & f & \% \\
\hline $\begin{array}{l}\text { Birinci el kaynakların görsellerinin gösterilmesi ya da slaytla yansıtılarak örnekler } \\
\text { verilmesi }\end{array}$ & 12 & 24 \\
$\begin{array}{l}\text { Sadece Epigrafi ve Paleografya derslerinde eski yazının öğrencilere tanıtılması ve } \\
\text { metin çevirisinin yapılması }\end{array}$ & 7 & 14 \\
$\begin{array}{l}\text { Birinci el kaynakların sınıfa getirilip öğrencilerle beraber okumalar ve } \\
\text { değerlendirmeler yapılması }\end{array}$ & 7 & 14 \\
$\begin{array}{l}\text { Birinci el kaynakların tanıtılması ve onlar hakkında bilgi verilmesi } \\
\text { Birinci el kaynaklardan bilgi aktarımı yapılması }\end{array}$ & 6 & 12 \\
$\begin{array}{l}\text { Ders notları ile belge karşıştırılması yapılması } \\
\text { Birinci el kaynaklardan alıntı yapılması ve alıntı yapılmasının tavsiye edilmesi }\end{array}$ & 6 & 12 \\
Birinci el kaynaklara nasıll ulaşıllacağının ve kullanılacağının öğretilmesi & 3 & 6 \\
Diğer & 2 & 4 \\
\hline Toplam & 6 & 4 \\
\hline
\end{tabular}

Tablo 7'de görüldüğ̈ü üzere öğrenciler lisans eğitimlerinde aldıkları derslerde birinci el kaynakların kullanım biçiminin nasıl olduğu sorusuna yönelik çeşitli görüşler bildirmişlerdir. Bunlar arasında en çok dile getirileni; birinci el kaynakların görsellerinin gösterilmesi ya da slaytla yansıt1larak örnekler verilmesi görüşüdür. Öğrencilerin bundan sonra sıraladıkları görüşler ise sadece Epigrafi ve Paleografya derslerinde eski yazının öğrencilere tanıtılması ve metin çevirisinin yapılması, birinci el kaynakların sınıfa getirilip 
öğrencilerle birlikte okumaların ve değerlendirmelerin yapılması, birinci el kaynakların tanıtılması ve onlar hakkında bilgi verilmesi, birinci el kaynaklardan bilgi aktarımı yapılması şeklindedir. Ders notları ile belge karşılaştırılması yapılması, birinci el kaynaklardan alıntı yapılması ve alıntı yapılmasının tavsiye edilmesi, birinci el kaynaklara nasıl ulaşılacağının ve kullanılacağının öğretilmesi ise daha az öğrenci tarafından ifade edilen görüşler arasındadır.

Diğer kategorisinde toplanan görüşler ise öğrencilerin daha ayrıntılı bilgiye ulaşmaları için birinci el kaynaklara yönlendirilmeleri, dersler sırasında ana kaynak olarak kullanılmaları, videolar izletilmesi, tarihi eserlerin maketlerinin gösterilmesi, öğrencilerin getirilen birinci el kaynakları incelemelerinin sağlanması, birinci el kaynaklarla ilgili soru cevap şeklinde konu anlatılmasıdır. Bu soruya toplamda 23 öğrenci ise cevap vermemiştir. Cevap vermeyenlerin çoğunluğu derslerinde kaynakların kullanılmadığını belirten öğrencilerdir. Konu hakkındaki görüşlerden bazı alıntılar ise aşağıda sunulmuştur:

Kat1lımc1 F28 "Tanıtıldı. Bazı klsa anekdotlardan bahsedildi."

Katılımc1 F13 "Slaytlarla anlatılarak ve içeriğinden örneklendirilerek bahsedildi."

Katılımc1 F5 "Orijinal kitaplar gösterildi ve öğrencilerle istişare edildi."

Katılımc1 F3 “Kaynak olarak bize o bilgiye nasıl ulaşmamız gerektiği hakkında bilgi vererek.”

Katılımcı E7 "Derslerde Osmanlıca okumalarının gelişmesi için kullanıldı."

Katılımc1 E16 "Epigrafi derslerinde metinler çevrilerek, yorumlanarak (kullanıldı)."

Katılımc1 E6 "Bazen belge karşılaştırması yapıyorduk. Genelde görsellerini yansıttıorlardı."

Katılımc1 E3 "Epigrafi derslerinde Osmanlıca okutulurken kullanıldı. Harfleri tanıtmak ve Osmanlıca metinlerinin okutulmasını ögretmek için (kullanıldı)."

Katılımc1 T12 "Örnek olarak gösterildi, nasıl faydalanılacă̆ı gösterildi."

Katılımc1 T13 “Dijital ortamda kullanıldı. Aynı zamanda bizzat materyali görerek inceledik.”

Katılımc1 F20 "Görsel olarak slayt şeklinde kitaplardan gösterildi."

\section{Öğrencilerin lisans eğitimlerinde birinci el kaynakların kullanımına dair eğitim alma durumları hakkındaki görüş̧leri}

Açık uçlu anket formu uygulanan tarih eğitimi anabilim dalı ve tarih bölümlerinde okuyan toplam 70 öğrenciye lisans eğitimleri sırasında birinci el kaynakların kullanımına dair eğitim alma durumları sorulmuş, elde edilen bulgular, frekans ve yüzdeleri ile aşağıdaki Tablo 8'de verilmiştir.

Tablo 8. Öğrencilerin Birinci Eı Kaynakların Kullanımına Dair Eğitim Alma Durumları

\begin{tabular}{lcc}
\hline Görüşler & F & \% \\
\hline Alanlar & 40 & 56 \\
Almayanlar & 15 & 21 \\
Kismen eğitim alanlar & 5 & 7 \\
Kendi çabaları ile bilgi edinenler & 1 & 1 \\
Cevap vermeyenler & 9 & 15 \\
\hline Toplam & 70 & 100 \\
\hline
\end{tabular}

Tablo 8'de görüldüğü üzere tarih öğrencilerinin çoğunluğu lisans eğitimlerinde birinci el kaynakların neler olduğuna ve bu kaynakların nasıl kullanılacağına dair eğitim aldıklarını belirtmişlerdir. Öğrencilerden 15'i bu konuda eğitim almadığını belirtirken beş öğrenci ise bu eğitimin kısmen verildiğini dile getirmiştir. Soruya dokuz öğrenci cevap vermezken, bir öğrenci (F12) de bu eğitimin öğretim üyeleri tarafindan verilmediğini, sadece kendi çabası ile kaynaklar hakkında bilgi sahibi olduğunu dile getirmiştir. 


\section{Öğrencilerin birinci el kaynakların kullanımına dair eğitim alma biçimleri hakkındaki görüşleri}

Lisans eğitimleri sırasında birinci el kaynakların kullanımına dair eğitim aldıklarını söyleyen tarih eğitimi anabilim dalı ve tarih bölümlerinde okuyan toplam 45 öğrenciye, bu eğitimleri ne şekilde aldıkları sorulmuş; elde edilen bulgular, frekans ve yüzdeleri ile aşağıdaki tablo 9'da verilmiştir.

Tablo 9. Öğrencilerin Birinci El Kaynakların Kullanımına Dair Eğitim Alma Biçimleri

\begin{tabular}{lcc}
\hline Görüşler & f & \% \\
\hline Kaynakların ne olduğuna ve nasıl kullanılması gerektiğine yönelik teorik & & \\
eğitim alma & 25 & 74 \\
Birinci el kaynakların kullanımına yönelik uygulama eğitimi alma & 9 & 26 \\
\hline Toplam & 34 & 100 \\
\hline
\end{tabular}

Tablo 9'da görüldüğü üzere öğrencilerden 25'i birinci el kaynakların ne olduğu, bu kaynakların türleri, nerelerde bulunacakları ve nasıl kullanılacakları konusunda eğitim aldıklarını ifade etmişlerdir. Öğrenciler bu eğitimlerin özellikle Tarih Metodolojisi ve Bibliyografya dersinde verildiğini belirtmişlerdir. Öğrencilerden dokuzu ise bu konuda uygulamaların da yapıldığını ancak bu uygulamaların Tarih Öğretim Yöntemleri dersinde olduğunu ifade etmişlerdir. Bu görüş de en çok tekrar edilen ikinci görüşü oluşturmuştur.

Konu hakkındaki görüşlerden bazı alıntılar aşağıda sunulmuştur:

Katılımc1 E15 "Tarih öğretim yöntemleri dersimizde bu belgeleri nasıl kullanacă̆ımıza, nasıl uygulamalar yapabileceğimize dair ĕgitim aldık. Birinci elden bir kaynakla ilgili öğrencilere çeşitli sorular sorarak onlarda bir fikir oluşturma yönünde çeşitli uygulamalar yaptık."

Katılımcı T11 "Birinci el kaynakları diğer yazılmış olan kroniklerle karşılaştırmayı ve doğru sonuçlar vermeyi ögrendim."

Katılımcı T4 "Evet derslerde hocalarımız anlatıma geçmeden dört hafta önce nasıl anlatacağımızı ve bu anlatımımızı yaparken neleri yapabileceğimizi örnek vererek ve video ile geçmiş sunumlardan örnek(lerle) göstermiştir."

Katılımc1 T8 "Evet, eğitim aldık. Birinci el kaynakların makale gibi akademik araştırmalarda önemi büyüktür. Ayrıca birinci el kaynaklara ulaşılması bir o kadar da zordur."

Katılımcı T20 "Elbette aldık. Bir tarihçi olarak birinci el kaynaklarla çok sık bir şekilde karşılaşma ve kullanma gibi bir durum söz konusu. Bundan mütevellit hocalarımı, birinci el kaynaklar üzerinde örnek göstererek (dersi) işlemeye büyük özen göstermekteydiler."

Katılımc1 E1 "5. Senemizin 1. Döneminde Tarih Öğretim yöntemleri dersinde birinci el kaynak kullanımını ögrendik. Uygulamaya çalıştık. Kanıtlar getirmeye çalıştık derse."

Katılımc1 F12 "Kendi çaba ve özel ilgimizle evet."

Katılımcı E6 "Metot dersinde nasıl ulaşacă̆ımızı, nerde olduklarını ögrrendik." 


\section{Sonuç, Tartışma ve Öneriler}

Lisans programlarında yer alan tarih derslerinde birinci el kaynakların kullanım durumunu tespit etmek amacıyla yürütülen çalışmanın bu bölümünde; bulgulara bağlı olarak ulaşılan sonuçların genel bir değerlendirmesi yapılmıştır.

Öğretim Üyeleri ile Yapılan Görüşmelerin Bulguları Üzerine Sonuçlar

Görüşme yapılan öğretim üyelerinin büyük çoğunluğunun derslerinde birinci el kaynakları kullandıkları belirlenmiştir. Öğretim üyeleri derslerinde en çok arşiv belgelerini daha sonra üst sıralarda kronikleri, resim ve fotoğrafları ve hatıratları kullandıklarını dile getirmişlerdir. Öğretim üyelerinin kaynak kullanımlarının değişiklik gösterdiği, bu durumu özellikle dersin konusunun belirlediği görülmüştür. Öğretim üyelerinden bazıları ise derslerinde birinci el kaynak kullanımının zorunlu bir süreç olduğunu, konularını bu kaynaklar üzerinden işlediklerini dile getirmişlerdir. Öğretim üyelerinden bir kısmı ise sınıflarda teknolojik donanımın yeterli olmamasından, dersin konusuna uygun birinci el kaynak bulamamalarından, birinci el kaynak kullanımının öğrenci seviyesine ve eğitim sistemine uygun olmadığını düşünmelerinden, farklı derslere girdikleri için derslere donanımlı ve hazır gelememelerinden dolayı derslerinde birinci el kaynak kullanamadıklarını dile getirmişlerdir.

Öğretim üyelerinin birinci el kaynakları kullanma amaçlarının, öğrencilere anlattığı bilgileri nereden aldığını göstermek ve bilgilerini temellendirmek, kaynakların niteliğini ve nasıl kullanılacağını göstermek; doğru ve güvenilir bilgiler sunmak ve öğrencileri akademik hayata hazırlamak noktalarında yoğunlaştığ 1 görülmektedir. Öğretim üyelerinden bazıları ise kullanım amaçlarını birinci el kaynakların faydaları yönünden değerlendirmiş, öğrencilerin derse ilgisini artırmak ve dersi somutlaştırmak gibi yararları sebebiyle bu kaynakları kullandıklarını ifade etmişlerdir.

Öğretim üyelerinin derslerinde kaynakları daha çok projeksiyon cihazı yardımıyla öğrencilere gösterip, bu görseller üzerinden örnekler vermek suretiyle kullandıkları görülmüştür. Böyle bir kullanım şeklini tercih etmelerinin nedenini ise projeksiyon cihazının kullanımının kolaylığına ve müfredatı yetiştirmek açısından zaman kazandırıcı olmasına bağladıkları tespit edilmiştir. Ayrıca bu görsellerin öğrencilerin zihninde canlandırma işlevini gördüğünü, böylece öğrencilerin aklında daha çok kaldığını ifade etmişlerdir. Bu sonuç Turan ve Aslan'ın (2015) öğretmen adayları ile yürüttüğü çalışmada görsel kaynakların tarihi bilgiyi somutlaştırdığ 1 ve daha anlaşılır kıldığ 1 bulgusu ile paralellik göstermektedir. Öğretim üyelerinin birinci el kaynakları kullanım biçimlerinde bundan sonra belirttikleri görüşler ise, farklı tarafların kaynaklarını birlikte kullanmak, karşılaştırmak ve öğrencilere kaynakların niteliğini, nerede bulunacaklarını ve nasıl kullanılacaklarını göstermek şeklindedir. Derslerinde birinci el kaynakları kullandıklarını söyleyen bazı öğretim üyeleri ise kaynakları sınıfa götürmeden, onlardan sadece sözel olarak bahsettiklerini ve örnekler verdiklerini dile getirmişlerdir. Bu durum bize öğretim üyelerinin birinci el kaynak kullanımı konusunda sınırlı davrandıklarını göstermektedir. Bir diğer sınırlılık ise sınıf içi kanıt kullanma etkinliklerinin birçoğunun öğretim üyeleri tarafından gerçekleştirilmemesi durumudur. Öğretim üyeleri daha az sıklıklarda ise öğrencilere birinci el kaynak niteliğindeki tarihi film ve belgesel izletme, birinci el kaynakların fotokopilerini ya da dönem gazetelerinin örneklerini öğrencilere verip onların incelemelerini sağlama, kaynaklardaki bilgilerin kesin ve doğru olup olmadığını tartışma, birinci el kaynak niteliğindeki haritaları gösterip dersi haritalar üzerinden yürütme görüşlerini ifade etmişlerdir.

Öğrencilere Uygulanan Açık Uçlu Anket Formundan Elde Edilen Bulgular Üzerine Sonuçlar

Öğrencilerin büyük çoğunluğunun derslerinde birinci el kaynak kullanıldığını ifade ettikleri tespit edilmiştir. Öğrenciler bu kaynakları başta arşiv kaynakları daha sonra kitaplar, vakanüvist tarihleri ve hatıralar şeklinde belirtmişlerdir. Görüşme yapılan öğretim üyelerinin derslerinde kullandıklarını söyledikleri birinci el kaynaklar ile açık uçlu anket formu uygulanan öğrencilerin derslerinde kullanıldığını söyledikleri birinci el kaynakların arşiv belgeleri noktasında örtüştüğü tespit edilmiştir. Öğrenciler derslerinde birinci el kaynakların kullanım sıklığını çoğunlukla dersin akışına göre, daha sonra hemen hemen her derste ve nadiren şeklinde belirtmişlerdir. 
Disiplinin merkezinde olan kanıtların tarih dersinde kullanılma şekli öğrencilerin geçmişi algılamaları üzerinde etkili olabilir (Phillips, 2008, 49-50). Öğrencilerin derslerinde birinci el kaynakların en çok görsellerinin gösterilerek ya da slaytla yansıtılıp örneklerinin verilerek kullanıldığı görüşünü paylaştıkları tespit edilmiştir. Bu, derslerinde kaynakları kullanım şekillerinde ögretim üyelerince de en çok dile getirilen görüşü oluşturmaktadır. Ancak bu örtüşme diğer kategorilerde görülmemiştir. Nitekim öğretim üyeleri birinci elden kaynakların kullanım şekillerini; karşılaştırma yapmak, kaynakların nerede bulunduklarını ve nasıl kullanılması gerektiğini öğretmek ve film, belgesel olarak izletmek şeklinde sıralanırken öğrenciler ise kullanım şekillerini; sadece Epigrafi ve Paleografya derslerinde metin çevirisinin yapılması ve eski yazının öğrencilere tanıtılması ve birinci el kaynakların sınıfa getirilip öğrencilerle beraber okumalar ve değerlendirmeler yapılması şeklinde sıralamışlardır. Öğretim üyeleri tarafından sık tekrarlanan kullanım biçimlerinden kaynak karşılaştırması yapma ve kaynakların nasıl kullanılması gerektiğini öğrencilere göstermenin öğrenciler tarafından çok az belirtilmesi ise değinilmesi gereken bir başka noktadır.

Öğrencilerin çoğunluğunun kaynaklar üzerinde eğitim aldıkları görülmüştür. Bu eğitimin biçimlerinin ilkin "kaynakların ne olduğuna ve nasıl kullanılması gerektiğine yönelik teorik eğitim" sonra da "birinci el kaynakların kullanımına yönelik uygulamalı eğitim" olduğu belirlenmiştir. Anlaşıldığı üzere tarih öğretmenliği ve tarih bölümü ögrencileri yani öğretmen adayları ve tarihçi adayları Osmanlıca öğretimi üzerine derslerde kaynaklar üzerinde okuma yaparken, özellikle Tarih Metodu/Tarih Metodu ve Bibliyografyası derslerinde birinci el kaynakların tarih yazımında kullanımına yönelik teorik eğitim almışlardır. Öğrencilerin Tarih Öğretim Yöntemleri dersinde ise birinci el kaynakların Ortaöğretimde kullanımına yönelik uygulamalı eğitim aldıkları anlaşılmaktadır. Katılımcıların cevaplarından kimi derslerde birinci el kaynaklar üzerinde değerlendirmelerin ve karşılaştırmaların yapıldığı da anlaşılmaktadır. Bunun dışında öğretim üyelerinden üçü kaynaklardaki bilgilerin kesin ve doğru olup olmadığını tartıştıklarını belirtirken bir öğretim üyesi Alan Çalışması diye adlandırdığı, programda ise adı ilk dönem Alan Eğitiminde Proje Hazırlama, ikinci dönemde ise Alan Eğitiminde Araştırma Projesi şeklinde geçen derste öğrencilerine birinci el kaynaklara dayalı çalışmalar yaptırdığını dile getirmiştir. Ancak öğretim üyelerinin ve öğrencilerin diğer sorulara verdikleri cevaplardan diğer derslerde öğrencilerin kaynakları kullanmalarına, bu konuda deneyim kazanmalarına yönelik uygulamaların sınırlı bir şekilde yapıldığı anlaşılmaktadır.

Araştırmada öğretim üyelerinin derslerinde çeşitli türlerde birinci el kaynak kullandıkları ve öğrencilerini bu kaynakların nasıl kullanılacağı konusunda bilgilendirdikleri görülmüştür. Ancak bu kaynakların sınıflarda geleneksel biçimde ele alındığı tespit edilmiş, ilgili literatürde gösterildiği üzere üst düzey düşünme becerilerinin geliştirilmesine yönelik kullanılmadığı belirlenmiştir. Buna ek olarak; gerek öğretim üyeleri gerekse öğrencilerden elde edilen bulgulara göre; birinci elden kaynakların tarih yazımında ve Ortaöğretimde kullanımına yönelik uygulamalı çalışmaların sınırlı kaldığı, öğrencilerin katılacağ1 etkinliklere yeterince başvurulmadığı ortaya konmuştur. Halbuki Zeichner ve Tabachnick'in (1981'den aktaran McCormick, 2004, 53) ifade ettiği üzere öğretmen adaylarının eğitim tecrübeleri, onların bu tür eğitim uygulamalarına yönelik inançlarını ve eğilimlerini etkilemektedir. Araştırmamızda elde edilen bu sonuç literatürdeki ilgili çalışmalarla benzerlik göstermektedir. Dilek ve Yapıcı $(2008,343)$ tarafından tarih öğretmen adaylarıyla gerçekleştirilen bir çalışmada da katılımcıların kaynaklarla çalışırken çeşitli zorluklar yaşadıkları tespit edilmiş ve ileride öğretmen olacak katılımcıların kaynaklarla çalışma konusunda yeterli düzeyde eğitim almaları önerilmiştir. Yazarlar; özellikle edebiyat fakültelerinde verilen öğretimin, öğrencilerin yaşadığı zorluklara göre gözden geçirilmesinin ve tarih metodolojisi dersinin öğrencilerin tarihsel kaynaklarla sağlıklı bir iletişim kurabilecekleri biçimde verilmesinin önemli olduğunu belirtmişlerdir. Dönmez ve Altıkulaç (2014, 938-939) tarafindan Sosyal Bilgiler öğretmen adaylarıyla yürütülen çalışmada ise katılımcıların tarihsel kaynakları kullanma konusunda bazı problemler yaşadıkları ve bu konuda aldıkları lisans eğitimlerini yeterli bulmadıkları ortaya konmuş ve öğretmen adaylarına lisans eğitimi dâhilinde tarihsel kaynakları beceri-temelli öğretim yönünde nasıl kullanabilecekleriyle ilgili eğitimin verilmesi önerilmiştir. Kiriş Avaroğulları ve Görgen, (2014, s.322) tarafindan tarih öğretmen adayları ile yürütülen araştırmada ise katılımcıların yazdıkları tarihsel metinlerde belirli bir bakış açısını benimseyerek bir argüman geliştiremedikleri, tezlerini uygun kanıtlarla destekleyemedikleri, çalışmalarının 
karşı1 tez ve görüşleri destekleyen kanıtlar içeremedikleri ve birincil kaynaklar kullanımı açısından yetersiz oldukları tespit edilmiştir. Öğretmen adaylarının birçok farklı kaynaklardan faydalanmadıkları ve yazım yöntemlerinin uygulanmasında bazı eksikliklerin olduğu elde edilen diğer bir bulgu olmuştur. Nitekim Kaya $(2015,2734)$ tarafından tarih ögretmen adaylarıyla gerçekleştirilen bir çalışmada katılımcıların kaynaklara dayalı öğretim uygulamalarında yaşadıkları sorunların en önemli nedeni; onların geçmişteki ve mevcut durumda lisans düzeyindeki eğitim hayatlarında kaynakların kullanımına dair bir deneyim yaşamamaları olarak tespit edilmiştir. Avcı Akçalı $(2019,243)$ tarafından tarih öğretmen adayları ile yürütülen çalışmada ise katılımcıların lisans programı derslerinde birinci el kaynakların kimi zaman ve de eleştirel incelemeye tabi tutulmadan kullanıldığını belirttikleri görülmüştür. Yazar, bundan dolayı tarih öğretmenliği lisans programlarda yer alan derslerde birinci el tarihi kaynakların eleştirel analize dayalı olarak kullanılmasını önermiştir. Bu araştırmamızda da genel olarak öğrencilerin lisans döneminde birinci el kaynaklara yönelik aldıkları eğitimin ortaöğretim tarih derslerinde birinci el kaynaklara dayalı öğretim etkinliklerini yürütebilmeleri için tam anlamıyla yeterli olmadığ görülmüştür.

\section{Öneriler}

1. Öğretim üyeleri, hem tarihçi hem de öğretmen adaylarının eğitiminde, birinci el kaynakları geleneksel yöntemler çerçevesinde kullanmak yerine, onların aktif olabileceği etkinlikler çerçevesinde kullanabilirler.

2. Tarih bölümlerinde ve Tarih eğitimi anabilim dallarında okuyan öğrenciler için birinci el kaynaklar üzerinden eğitim sadece Tarih Metodolojisi ve Tarih Öğretim Yöntemleri gibi derslerle sınırlı kalmamalıdır. Lisans düzeyinde diğer derslerde de özellikle uygulamalı, öğrencilerin etkin olduğu birinci el kaynak kullanımlarına yer verilmelidir. Bu uygulamaların öğrencilerin ileride mesleki yaşamlarında yansımasını bulacağı unutulmamalıdır (Bkz. Kabapınar, 2008, 328; Tuncel, 2019, 351). Bunun için birinci el kaynak kullanımına yönelik olarak lisans düzeyinde okutulan ders kitaplarına etkinlikler konabilir, öğretim üyeleri için kılavuz kitaplar hazırlanabilir.

3. Tarih eğitimi anabilim dalında okuyan öğrencilere lisans eğitimlerinde, tarih bölümü okuyan öğrencilere de pedagojik formasyon eğitimlerinde, birinci el kaynakların, kanıtların çeşitli etkinliklerle beceri kazanımına yönelik nasıl kullanılabileceği gösterilmelidir (Bkz. Dönmez \& Altıkulaç, 2014, 939). Hatta kendilerine çeşitli düşünme becerilerini geliştirmeye yönelik, kanıt kullanımına dayalı araştırma ödevleri verilmelidir. Bu çalışmalar onların eleştirel düşünme becerilerine katkı sağlayacağı gibi (Bkz. Avc1 Akçalı, 2019, 243) ileride öğretmenlik hayatlarında uygulayabilecekleri modeller oluşturmalarına katkı sağlayacaktır.

4. Çalışma konusu farklı üniversitelerde de ele alınıp, araştırılarak literatür zenginleştirilebilir. Konu ile ilgili literatürün zenginleşmesi, tarih eğitimcilerine konuya dair daha geniş bir perspektif sağlayacaktır. 


\section{Kaynakça}

Acun, F. (2011). Tarihin kaynakları. A. Şimşek (Edt.). Tarih nasıl yazılır? Tarihyazımı için çă̆daş bir metodoloji içinde (s. 119-149). İstanbul: Tarihçi Kitabevi.

Alabaş, R. (2007). İlköğretim 6. sınıf sosyal bilgiler dersinde kanıt temelli ögrenme modeli: Bir eylem araştırması. Yayınlanmamış yüksek lisans tezi. Marmara Üniversitesi, Eğitim Bilimleri Enstitüsü, İstanbul.

Avcı Akçalı, A. (2019). Tarih öğretmen adaylarının eleştirel düşünme becerilerinin geliştirilmesine yönelik bir eylem araştırması. Kastamonu Eğitim Dergisi, 27 (1), 231-246. https://dergipark.org.tr/tr/download/article-file/458991 adresinden 5 Ocak 2020'de alınmıştır.

Balkaya, A. (2002). İlköğretim sosyal bilgiler dersi tarih konularının öğretiminde tarihsel kanıtların etkililiği. Yayınlanmamış yüksek lisans tezi. Marmara Üniversitesi, Eğitimi Bilimleri Enstitüsü, İstanbul.

Bilgiç, S. (2018). İlkokul 4. sınıf sosyal bilgiler derslerinde kanıt temelli öğrenmeye ilişkin bir eylem araştırması. Yayınlanmamış yüksek lisans tezi. Sakarya Üniversitesi, Eğitim Bilimleri Enstitüsü, Sakarya.

Black, J. \& MacRaild, D.M. (2016). Tarih çalışmak (3. baskı). (N. Bozbora, çev.). Ankara: Yayınodası Yayıncilik.

Çıdaçı, T. (2015). Sosyal bilgiler dersi tarih konularının öğretiminde birinci elden kaynakların kullanımı (7. sınıf örneği) (Kanıt temelli öğrenme). Yayınlanmamış yüksek lisans tezi. Muğla Sıtkı Koçman Üniversitesi, Eğitim Bilimleri Enstitüsü, Muğla.

Çiftarslan, N. (2019). 8. sınıf T.C. İnkılap Tarihi ve Atatürkçülük dersinde kanıt temelli öğrenme yaklaşımı ile tarih öğretimi: Fenomenolojik bir çalışma. Yayınlanmamış yüksek lisans tezi. Marmara Üniversitesi, Eğitim Bilimleri Enstitüsü, İstanbul.

Çulha Özbaş, B. (2010). 12-14 yaş grubu öğrencilerinin tarihsel düşünme gelişimi ve tarihsel kanıt kullanımı. Yayınlanmamış doktora tezi. Dokuz Eylül Üniversitesi, Eğitim Bilimleri Enstitüsü, İzmir.

Dilek, D. \& Yapıcı, G. (2008). Tarih öğretmen adaylarının kaynaklarla çalışmada karşılaştıkları güçlükler ve romantik tarih anlayıșı: Sınav kağıtları üzerine bir analiz. M. Safran \& D. Dilek (Edt.) 21. yüzyılda kimlik, vatandaşlık ve tarih eğitimi içinde (s. 330-344). İstanbul: Yeni İnsan Yayınevi.

Dinç, E. (2014). Tarih öğretiminde yazılı kaynakların kullanımı. İ.H. Demircioğlu \& İ, Turan (Edt.), Tarih ögretiminde ögretim teknolojileri ve materyal tasarımı içinde (2. Bask1), (s. 75-115). Ankara: Pegem Akademi.

Doğan, N. (2008). İlköğretim 8. sınıf Türkiye Cumhuriyeti inkılâp tarihi ve Atatürkçülük dersinin öğretiminde tarihsel kanıt kullanımının etkililiği. Yayınlanmamış yüksek lisans tezi. Marmara Üniversitesi, Eğitim Bilimleri Enstitüsü, İstanbul.

Doğan, Y. (2007). Sosyal bilgiler öğretiminde tarihsel yazılı kanıtların kullanımı. Yayınlanmamış doktora tezi. Gazi Üniversitesi, Eğitim Bilimleri Enstitüsü, Ankara.

Doğan, Y. (2008) Sosyal bilgiler öğretiminde tarihsel yazılı kanıt kullanmanın öğrencilerin akademik başarısına etkisi. Türkiye Sosyal Araştırmalar Dergisi, 12 (2), 171-186.

Doğan, Y. \& Dinç, E. (2007) Birinci elden tarih kaynaklarının sosyal bilgiler ve tarih derslerinde internet üzerinden kullanımı: ABD ve İngiltere'den uygulama örnekleri. Türkiye Sosyal Araştırmalar Dergisi $11(2), 195-220$. 
Dönmez, C. \& Altıkulaç, A. (2014). Sosyal bilgiler öğretmen adaylarının ortaokul TC İnkılâp Tarihi ve Atatürkçülük dersi konularının öğretiminde tarihsel kaynakların kullanımına yönelik görüşleri. Kastamonu Ë̆itim Dergisi, 22 (3), 923-942.

Gibson, L. (2014). Teaching student teachers to use primary sources when teaching history. In. R. Sandwell and A. Heyking (Eds.), Becoming a history teacher: Sustaining practices in historical thinking and knowing (pp. 214-225). Toronto: University of Toronto Press.

Güler, A, Halıcıoğlu, M.B. \& Taşğın, S. (2013). Sosyal bilimlerde nitel araştırma yöntemleri. Ankara: Seçkin Yayınc1lik.

Iş1k, H. (2008a). Tarih öğretiminde doküman kullanımının öğrencilerin tarihsel düşünme becerilerine ve başarılarına etkisi. Yayınlanmamış doktora tezi. Gazi Üniversitesi, Eğitim Bilimleri Enstitüsü, Ankara.

Işık, H. (2008b). İlköğretim 4. sınıf sosyal bilgiler tarih konularının öğretiminde kanıt temelli öğrenme modeli: Bir aksiyon araştırma. Yayınlanmamış yüksek lisans tezi. Marmara Üniversitesi, Eğitim Bilimleri Enstitüsü, İstanbul.

Kabapınar, Y. (2003). Eğitim pedagojisi ve tarih metodolojisi açısından ingiliz tarih ders kitaplarına bir bakış. Tarih ve Toplum, 39/230, 40-47.

Kabapınar, Y. (2008). Sosyal bilgiler öğretmen adaylarının sosyal bilimlerin/ tarihin metodolojisi ve dersin öğretim amaçlarına ilişkin görüşleri: “Ötekiler” üzerinden "biz”i değerlendirmek. M. Safran \& D. Dilek (Edt.). 21. yüzyılda kimlik, vatandaşlık ve tarih eğitimi içinde (s. 316-329). İstanbul: Yeni İnsan Yayınevi.

Kabapınar, Y. (2014). Kuramdan uygulamaya sosyal bilgiler öğretimi (4. baskı). Ankara: Pegem Akademi.

Kabapınar, Y. (2019). Kanıt temelli öğrenme; tanım, kapsam, yaklaşımlar. Y. Kabapınar (Edt.). Kimlik belirleyen derslerde kanıt temelli öğrenme içinde (s. 29-54). Ankara: Pegem Akademi.

Karasar, N. (1999). Bilimsel araştırma yöntemi, -kavramlar, ilkeler, teknikler-. Ankara: Nobel Yayın Dağıtım Ltd. Şti.

Kaya, R. (2015). Problems encountered during the implementations of resource-based teaching in pre-service history teacher training, Educational Research and Reviews, 10 (20), 2724-2736, https://academicjournals.org/journal/ERR/article-full-text-pdf/0E9BA0D55894 adresinden 20 Mart 2019 tarihinde alınmıştır.

Keating, J. and Sheldon, N. (2011) History in education: Trends and themes in history teaching, 1900-2010. In Ian Davies (Ed.), Debates in history teaching, (pp.5-17). London and New York: Routledge.

Keleş, H., Ata, B. \& Köksal, İ. (2006). Tarihî dokümanla tarih öğretiminin lise öğrencilerinin başarısına etkisi. G.Ü. Gazi Ĕ̈itim Fakültesi Dergisi, 2, 99-112.

Kiriş Avaroğulları. A. \& Görgen. İ. (2014). Historiographical capacity of pre-service history teachers in Turkey. US-China Education Review A, 4 (5), 312-324. http://www.davidpublisher.org/Public/uploads/Contribute/55122419b1f4a.pdf adresinden 26 Haziran 2020 tarihinde alınmıştır.

McCormick, T. M. (2004). An exploration in how elementary teacher candidates read, select, and use primary documents (Order No. 3155885). Available from ProQuest Dissertations \& Theses Global. (305209507). http://search.proquest.com/docview/305209507? accountid=8403 adresinden alınmıştır.

Merriam, S. B. (2013). Nitel araştırma: Desen ve uygulama için bir rehber. (Üçüncü Basımdan Çeviri) (S. Turan. çev.). Ankara: Nobel Yayıncılık. 
Milli Eğitim Bakanlığı (2007). Tarih dersi öğretim programı (9. Sinıf), Ankara: Talim ve Terbiye Kurulu Başkanlı̆̆

Milli Eğitim Bakanlığı. (2018). Ortaögretim tarih dersi (9.10 ve 11. Sinıflar) öğretim programı. Ankara: Talim ve Terbiye Kurulu Başkanlığı. http://mufredat.meb.gov.tr/ProgramDetay.aspx?PID=344 adresinden edinilmiştir.

Osborne, K. (2003). Voices from the past, primary sources: A new old method of teaching history. Canadian Social Studies, 37 (2), https://canadian-social-studies-journal.educ.ualberta.ca/content/articles-20002010\#CLvoices_from the past150 adresinden 20.10.2020 tarihinde alınmıştır.

Phillips, I. (2008). Teaching history: developing as a reflective secondary teacher. London: SAGE Publications Ltd.

Sylvester, D. (1997). Change and continuity in history teaching 1900-93. In Hilary Bourdillon (Ed.). Teaching History (p. 9-23). Routledge: London.

Şener, N. (2019). Ortaokul sosyal bilgiler dersinde tarihsel kanıt kullanımının öğrencilerin tutumlarına etkisi ve öğretmen görüşleri. Yayınlanmamış yüksek lisans tezi. Erciyes Üniversitesi, Eğitim Bilimleri Enstitüsü, Kayseri.

Tuncel, G. (2019). Kanıt temelli öğrenme temelinde bir öğretmen adayı eğitimi programının öyküsüne bakmak Y. Kabapınar (Edt.). Kimlik belirleyen derslerde kanıt temelli ögrenme içinde (s. 333-353). Ankara: Pegem Akademi.

Turan, İ. \& Aslan, H. (2015). Öğretmen adaylarının tarihi görselleri analiz düzeyleri. Turkish History Education Journal (TUHED), 4 (2), 87-112. https://dergipark.org.tr/tr/download/article-file/164061 adresinden alınmıştır.

Tuş, M. (2015). Tarihçi ve kaynak. A. Şimşek (Edt.). Tarih için metodoloji içinde (s. 232- 236). Ankara: Pegem Akademi.

Yalı, S. \& Şimşek, A. (2019). Tarih, tarihçi. tarihyazımı ve "kanıt": Teorik bir sorgulama. Y. Kabapınar (Edt.). Kimlik belirleyen derslerde kanıt temelli öğrenme içinde (s. 19-27). Ankara: Pegem Akademi.

Yetiş, A. (2018). Öğretmen ve öğrencilerin 'kanıt temelli tarih öğretimi'ne ilişkin görüşleri: Bir durum saptaması. Yayınlanmamış yüksek lisans tezi. Marmara Üniversitesi, Eğitim Bilimleri Enstitüsü, İstanbul.

Yıldırım, A. \& Şimşek, H. (2013). Sosyal bilimlerde nitel araştırma yöntemleri. (9. basım). Ankara: Seçkin Yayınc1lik. 